\title{
Gallsteinasjúkdómar hjá punguðum konum á Landspítala 1990-2010
}

\author{
Hörður Már Kolbeinsson læknir¹, Hildur Harðardóttir læknir ${ }^{1,2}$, Guðjón Birgisson ${ }^{1,3}$, Páll Helgi Möller læknir ${ }^{1,3}$
}

\section{A G R I P}

Inngangur: Gallblöđrutaka um kviðsjá er talin örugg aðgerð á meðgöngu, óháð meðgöngulengd. Ekki er vitað hver kjörmeðferð er við gallsteinasjúkdómum hjá punguðum konum. Talið hefur verið að meðferð án aðgerðar skili bestum árangri á fyrsta og priðja priðjungi meðgöngu en skurðmeðferð sé öruggust á öđrum priðjungi. Tilgangur rannsóknarinnar var að kanna tíðni, orsakir, greiningu og árangur gallblöðrutöku hjá punguðum konum á Landspítala á tímabilinu 1990-2010.

Efniviður og aðferðir: Rannsóknin var afturskyggn og tók til allra kvenna er lögðust inn á Landspítala með gallsteinasjúkdóm međan á pungun stóð og allt að 6 vikum eftir fæðingu. Skráðar voru meðal annars upplýsingar um aldur, einkenni, vefjagreiningu og pyngdarstuðul ásamt ASA-flokkun og fylgikvillum aðgerða hjá peim konum sem gengust undir gallblöðrutöku á tímabili rannsóknarinnar.

Niðurstöður: Á rannsóknartímabilinu voru 77 konur lagðar inn með gallsteinasjúkdóma í samtals 139 innlögnum og nýgengi pví 0,09\%. Gallsteinagreiningar voru gallkveisa $(n=59)$, brisbólga $(n=1)$, gallgangasteinar $(n=10)$ og bráđ gallblöđrubólga $(n=7)$. Algengasta ástæða innlagnar var verkur í efri hægri fjórðungi kviðar ( $n=63$ ). Fylgikvillar gallsteinasjúkdóma tengdir meðgöngu voru fyrirburafæðingar $(n=2)$. Fimmtán konur gengust undir aðgerð á meðgöngu og 17 á 6 vikna tímabili eftir fæðingu en fylgikvillar aððgerða voru helst steinar í gallgangi $(n=2)$. Meðal pyngdarstuðull sjúklinga var 31,1 og algengasta ASA-flokkun var 1 (bil: 1-3). Flest vefjasvör sýndu langvinna bólgu $(n=24)$ og bráða bólgu $(n=5)$ í gallblöðru. Ályktun: Gallsteinasjúkdómar pungaðra kvenna eru fátíðir, hafa í för með sér endurteknar innlagnir en tíðni fylgikvilla er lág. Gallblöđrutaka með kviðsjá hjá punguðum konum á Landspítala er örugg ađgerð, sem er í samræmi við erlendar niðurstöður.

\section{Inngangur}

Áhrif hormóna á meðgöngu valda pví að gallsteinar eru algengari meðal pungaðra kvenna en annarra kvenna. Prógesterón dregur úr hreyfingum gallblöðru og estrógen eykur kólesterólmagn í galli. Saman auka pau líkurnar á myndun gallsteina. ${ }^{1}$ Talið er að allt að $12 \%$ pungaðra kvenna hafi gallsteina hverju sinni og að um $0,8 \%$ peirra geti purft að leggjast inn á spítala vegna gallsteinasjúkdóms. ${ }^{2-4}$ Alvarlegir gallsteinasjúkdómar hjá punguðum konum á borð við bráða gallblöðrubólgu, gallgangabólgu (cholangitis) og gallsteina-brisbólgu eru hins vegar sjaldgæfir með tíðni á bilinu 0,01-0,05\%. ${ }^{5}$ Gallblöðrutaka ásamt botnlangatöku eru algengustu skurðaðgerðirnar sem framkvæmdar eru á punguðum konum, ótengdar meðgöngu (non-obstetrical operations). ${ }^{6}$ Kjörmeðferð við gallsteinasjúkdómum í pessum sjúklingahópi hefur ekki verið vel skilgreind og lengst af hefur verið mælt með íhaldssamri meðferð. Með íhaldssamri meðferð hefur hugsunin verið að draga úr tíðni fósturláta og fyrirburafæðinga sem talin voru fylgja opinni aðgerð. ${ }^{7}$ Ókostir peirrar meðferðar er hins vegar aukin tíðni sjúkdómsendurkomu sem er algengari pví fyrr sem konur greinast á meðgöngu. ${ }^{4,8-12}$ Pá hafa rannsóknir sýnt yfir 20\% tíðni bráðrar

${ }^{1}$ Læknadeild Háskóla Íslands, ${ }^{2}$ kvensjúkdómadeild, ${ }^{3}$ skurðlækningadeild Landspítala. Fyrirspurnum svarar Páll Helgi Möller pallm@landspitali.is

Höfundar hafa útfyllt eyðublað um hagsmunatengsl.

https://doi.org/10.17992//bl.2016.12.110

Greinin barst 24. maí 2016, sampykkt til birtingar 20. október 2016. gallblöðrubólgu eða brisbólgu hjá peim konum sem greinast upphaflega með gallkveisu (biliary colic) og aukna tíðni fósturláta og fyrirburafæðinga hjá peim sem meðhöndlaðar eru án skurðaðgerðar. ${ }^{4,13,14}$

Gallblöðrutaka um kviðsjá er talin örugg aðgerð á meðgöngu en samkvæmt leiðbeiningum Society of American Gastrointestinal and Endoscopic Surgeons (SAGES) frá 2011 er mælt með að pungaðar konur sem greinast með gallsteinasjúkdóma á meðgöngu séu teknar til aðgerðar, óháð meðgöngulengd.,15

Á Íslandi hefur ekki áður verið gerð samantekt á afdrifum peirra kvenna sem greinst hafa með gallsteinasjúkdóm á meðgöngu. Tilgangur rannsóknarinnar var pví að kanna einkenni, greiningu, meðferð og afdrif peirra kvenna sem greindust með gallsteina á meðgöngu á Landspítala.

\section{Efniviður og aðferðir}

Rannsóknin var afturskyggn og náði yfir tímabilið 1. janúar 1999 til 31. desember 2010. Bornar voru saman Fæðingarskrá (landskrá fæðinga) og greininganúmer fyrir gallsteinasjúkdóma (K80-K85) samkvæmt greiningakerfi Alpjóðaheilbrigðisstofnunarinnar (International Classification of Diseases, ICD) og pær konur fundnar sem greindar voru með gallsteinasjúkdóm á tímabilinu meðan pungun stóð yfir. Upplýsingar voru fengnar úr sjúkraskrám, rafrænum sjúkraskrárkerfum Landspítala og frá rannsóknarstofu Háskólans í meinafræði. Skráðar voru upplýsingar um legutíma, 
Tafla I. Aldursdreifing, fjöldi innlagna per konu og legutími.

\begin{tabular}{lc}
\hline Fjöldi sjúklinga & $\mathrm{n}=77$ \\
Meðalaldur & 29 (bil: 19-43) \\
\hline Meðal innlagnarföldi & $1,8$ (bil: $1-7)$ \\
\hline Legutími í dögum (miðgildi) & 1 (bil: $1-31)$ \\
\hline
\end{tabular}

einkenni, meðgöngulengd við greiningu og fæðingu, myndgreiningar, niðurstöður myndgreininga, fylgikvilla og fósturlát ásamt vefjagreiningum hjá peim konum sem gengust undir aðgerð. Farið var yfir aðgerðarlýsingar og svæfingarskrár hjá peim konum sem fóru í gallblöðrutöku á ofangreindu tímabili og aðgerðartími, pyngd og hæð sjúklings, ASA-flokkun og fylgikvillar aðgerðar skráð. Nýgengi var reiknað út frá tölum um fæðingar á vef Hagstofu Íslands á árunum 1990-2010.16 Tilskilin leyfi frá vísindasiðanefnd Landspítala og Persónuvernd voru fengin fyrir rannsókninni. Upplýsingar voru skráðar í tölvuforritið Microsoft Excel ${ }^{\circledR}$ (Microsoft, Redmond WA).

\section{Niðurstöður}

Rannsóknarpýđi og sjúkdómsgreiningar

Alls greindust 182 konur með gallvegasjúkdóm á meðgöngu og 6 vikum eftir barnsburð á tímabilinu 1990-2010. Níutíu og sjö konur voru útilokaðar par sem greining átti sér stað á 6 vikna tímabilinu eftir barnsburð. Sjö konur voru útilokaðar vegna rangrar greiningar og ein vegna pess að sjúkraskrá fannst ekki. Рað voru pví 77 konur sem uppfylltu skilyrði rannsóknarinnar. Nýgengi gallsteinasjúkdóma á rannsóknartímabilinu reiknast pví 0,09\%. Upplýsingar um meðalaldur, legutíma og fjölda innlagna má finna í töflu I.

Flestar konurnar fengu greininguna gallkveisa á rannsóknartímabilinu (n=59, 76,6\%). Aðrar greiningar voru bráð gallblöðrubólga, gallgangasteinar (choledocholithiasis) eða gallsteina-brisbólga (tafla II). Prjár konur fengu greininguna brisbólga en einungis í einu tilfelli var hægt að tengja hana við gallsteina. Hin tvö tilfellin voru annars vegar brisbólga í kjölfar gallvegaspeglunar (endoscopic retrograde cholangiopancreatography, ERCP) par sem fjarlægðir voru steinar úr gallgangi og hins vegar brisbólga af óljósum toga par sem ekki voru greindir gallsteinar í gallblöðru eða gallgöngum á

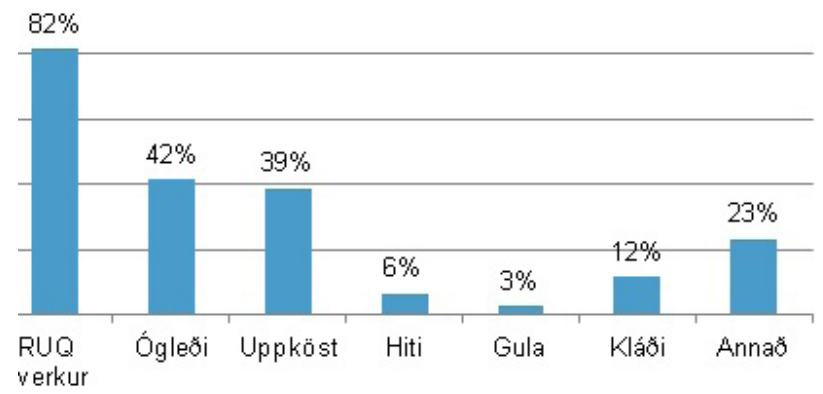

Mynd 1. Einkenni við greiningu. Hver súla sýnir hlutfall sjúklinga með tiltekið einkenni. $R U Q=$ right upper quadrant (hægri efri fjórðungur kviðar).
Tafla II. Greiningar kvenna rannsóknarinnar.

\begin{tabular}{lc}
\hline Fjöldi sjúklinga & $\mathrm{n}=77$ \\
\hline Gallkveisa & 59 \\
\hline Bráð gallblöðrubólga & 7 \\
\hline Brisbólga & 1 \\
\hline Gallgangasteinar & 10 \\
\hline
\end{tabular}

myndrannsóknum. Ekkert tilfelli sýkingar í gallgöngum átti sér stað á meðal rannsóknarpýðis.

\section{Klínísk birtingarmynd, greiningaraðferðir og aðgerðir}

Algengasta einkennið sem konur höfðu við komu var verkur í efri hægri fjórðungi kviðar með eða án leiðni aftur í bak eða upp í herðablöð (n=63). Önnur einkenni voru fátíðari en ógleði, uppköst og kláði voru tiltölulega algeng einkenni (mynd 1). Meðal einkenna sem féllu í flokkinn "Annað“ voru niðurgangur ( $(n=5)$, öndunarópægindi $(\mathrm{n}=5)$ og dökkt pvag $(\mathrm{n}=2)$ ásamt öðrum sjaldgæfari einkennum á borð við slappleika, hroll, minnkaða matarlyst og ljósar hægðir.

Algengasta myndrannsóknin var ómskoðun en 70 konur (91\%) voru greindar pannig. Í flestum tilfellum var ómun eina myndrannsóknin sem gerð var. Tvær konur fóru í kjölfar ómunar í gallvegaspeglun og prjár í segulómun af gallvegum (magnetic resonance cholangiopancreatography, MRCP) vegna gruns um steina í gallvegum. Í fjórum tilfellum fóru konur bæði í segulómun og í gallvegaspeglun í kjölfar ómunar. Ein kona hlaut greiningu með segulómunarrannsókn og gallvegaspeglun án undangenginnar ómskoðunar en pá hafði gallblaðran pegar verið fjarlægð. Engar myndrannsóknir af gallblöðru eða brisi fundust hjá 6 konum en líklegt verður að teljast að greining hafi pá farið fram utan Landspítala.

Af 77 konum rannsóknarinnar fóru 32 í gallblöðrutöku á rannsóknartímabilinu, 15 á meðgöngu og 16 innan 6 vikna frá fæðingu. Ábendingar fyrir aðgerðum voru bráð gallblöðrubólga $(n=6)$ eða endurtekin gallkveisa $(n=26)$. Allar aðgerðirnar voru framkvæmd-

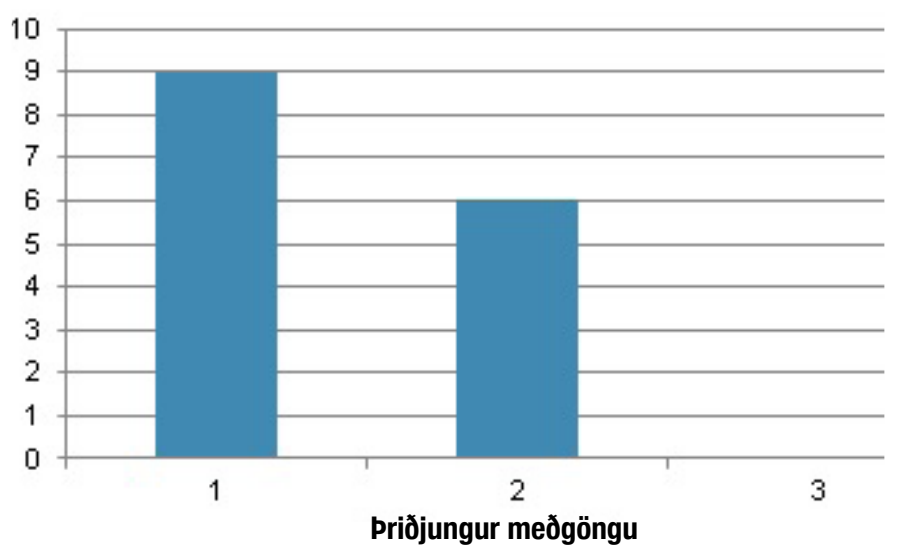

Mynd 2. Fjöldi gallblöðrutakna á hverjum priðjungi meðgöngu. 
ar í kviðsjá fyrir utan eina opna aðgerð par sem gallblaðran var fjarlægð samhliða keisaraskurði. Mynd 2 sýnir dreifingu aðgerða eftir priðjungum meðgöngu.

Fjörutíu og fimm konur gengust ekki undir gallblöðrutöku á tímabili pungunar né innan 6 vikna eftir fæðingu. Af pessum 45 konum höfðu 30 farið í aðgerð frá tímabili rannsóknarinnar (31. desember 2010) og til 1. maí 2012 en prjár peirra höfðu látið fjarlægja gallblöðruna fyrir meðgöngu og greindust með gallsteina í gallgöngum.

\section{Afdrif}

Fimm konur fæddu fyrir áætlaðan fæðingardag, par af tvær $(2,6 \%)$ mögulega vegna vandamála tengd gallsteinunum. Önnur fyrirburafæðingin var í tilfelli konu sem pegar hafði fengið gallblöðruna fjarlægða. Hún leitaði læknis vegna kláða og við skoðun reyndist konan hafa hækkun á lifrarprófum og pví talin vera með gallstasa (cholestasis). Ómun af gallvegum sýndi pó eðlilega víða gallvegi innan og utan lifrar. Í kjölfarið var ákveðið að framkalla fæðingu við 35 vikur. Hin fyrirburafæðingin var hjá konu sem var lögð inn með verk í hægri efri fjórðungi kviðar ásamt ógleði og uppköstum. Ómun sýndi stein í gallblöðru og pykknun í vegg gallblöðrunnar sem benti til bráðrar gallblöðrubólgu. Í samráði við fæðingarlækni var framkvæmdur keisaraskurður og opin gallblöðrutaka eftir rúmlega 36 vikna meðgöngu par sem gallblaðran var fjarlægð í kjölfar fæðingar barnsins. Bæði börnin fæddust heilbrigð. Hin prjú tilfelli fyrirburafæðinga voru rakin til meðgöngueitrunar og pvagfærasýkingar.

Ein andvana fæðing varð á tímabili rannsóknarinnar hjá konu eftir 38 vikna meðgöngu. Gallblöðrutaka hjá peirri konu var gerð í kviðsjá á öðrum priðjungi meðgöngu og var fylgikvillalaus. Konan hafði engin frekari einkenni gallsteinasjúkdóms eftir aðgerðina. Fæðingin varð meira en 30 dögum eftir gallblöðrutökuna og var ekki hægt að rekja pað til gallsteinasjúkdóms eða aðgerðar móður að barnið fæddist andvana.

Hvað skurðaðgerðir varðar var hvorki hægt að rekja fyrirburafæðingu, fósturlát né andvana fæðingu til aðgerðar. Í tveimur tilfellum (6\%) greindust gallsteinar í gallgöngum eftir aðgerð og hjá báðum var í kjölfarið gerð gallvegaspeglun.

Líkamspyngdarstuðull kvennanna var að meðaltali 31 (bil: 2149). Pær voru almennt hraustar, par sem miðgildi ASA-skors var 1 (bil: 1-3). Aðgerðartími var að meðaltali 63 mínútur (bil: 36-105).

Flestar vefjagreiningar sýndu langvinna gallblöðrubólgu $(\mathrm{n}=24)$ en í 5 tilfellum sýndi hún bráđa gallblöðrubólgu. Í einu sýni voru steinar án bólgu og í tveimur var engin vefjagreining gerð en einnig er mögulegt að vefjarannsókn hafi farið fram annars staðar en á Landspítala.

\section{Umræða}

Nýgengi gallsteinasjúkdóma meðal pungaðra kvenna sem krefjast innlagnar á Landspítala er 0,09\% og meðalaldur er 29 ár sem er svipað og hefur verið lýst erlendis. ${ }^{17,18}$ Konurnar voru lagðar inn að meðaltali 1,8 sinnum á rannsóknartímabilinu og fjöldi innlagna á hverja konu var á bilinu 1 til 7 en viðbúið er að sjá endurteknar, stuttar innlagnir hjá konum með gallsteinasjúkdóma sem meðhöndlaðar eru án skurðaðgerðar. ${ }^{8,9,14}$ Tímasetningar gallsteinagreininga á meðgöngu voru ekki skoðaðar sérstaklega en pað var sökum pess að stór hluti kvennanna hafði gallsteinagreiningu fyrir meðgöngu og svo endurtekin köst á meðgöngutíma.

Birtingarmynd gallsteinasjúkdóma getur verið mjög fjölbreytileg. Algengasta einkennið er verkur í efri hægri fjórðungi kviðar og pað breytist ekki í tilfellum pungaðra kvenna. ${ }^{19}$ Sú var einnig raunin í pessari rannsókn par sem $82 \%$ kvenna fundu slík einkenni. Ógleði og uppköst eru algengur fylgifiskur gallsteinasjúkdóma líkt og niðurstöður bera vitni um en 32\% og 30\% kvenna upplifðu ógleði og uppköst ein og sér eða með öðrum einkennum. Í fæstum tilvikum höfðu sjúklingar gulu, sem bendir til pess að fáar pungaðar konur fái stíflu í gallgöngum pó svo að steinar finnist með MRCP eða við ómun. Pað minnkar líkur á sýkingu í gallgangi pótt talið sé að $12 \%$ tilfella fái ekki einkenni gulu eða hita við gallgangasýkingu. ${ }^{20}$

Bráð gallblöðrubólga og brisbólga vegna gallsteina reyndust fátíðar í rannsókninni (10\%) en pað er sambærilegt við pað sem hefur birst hjá öðrum höfundum, pó algengi uppá $23 \%$ hafi verið lýst. ${ }^{21}$ раð kom ekki á óvart að meðgöngutengdir fylgikvillar reyndust einnig fátíðir, með tíðni fyrirburafæðinga upp á 3\% sem er mjög sambærilegt við erlendar niðurstöður. ${ }^{11,22,23}$ Engin fósturlát tengdust gallsteinasjúkdómum á Landspítala en lýst hefur verið allt að $7 \%$ tíðni erlendis. ${ }^{10}$

Í peim tilfellum sem gögn um myndgreiningu voru til staðar gengust allar konurnar nema ein undir ómun, sem er sú rannsókn sem hentar einna best í tilfellum pungaðra kvenna, en hún er án geislunar, ódýr og með gott næmi fyrir steinum í gallblöðru. ${ }^{15}$ Átta konur voru greindar með segulómun af gallvegum og voru pað tilfelli par sem grunur var um steina í gallgangi, gefið til kynna með ómskoðun eða hækkun á lifrarprófum. Segulómskoðun af gallvegum er einnig rannsókn sem talin er henta vel punguðum konum sem taldar eru vera með gallsteina í gallgangi par sem hún er án geislunar. Mælt er með að rannsóknin sé framkvæmd án gadolinium skuggaefnis par sem áhrif pess á fóstur eru ekki pekkt að fullu pó að ekki hafi tekist að sýna fram á að skaðleg áhrif pess á fóstur hingað til. ${ }^{24}$

Fylgikvillar gallsteinasjúkdóma er sneru að punguninni voru fátíðir. Af 32 aðgerðum voru 15 aðgerðir framkvæmdar á meðgöngu en 17 aðgerðir fóru fram á fyrstu 6 vikunum eftir fæðingu og voru allar aðgerðirnar nema ein framkvæmdar um kviðsjá. Pessi fjöldi aðgerða svo stuttu eftir meðgöngu gefur upplýsingar um hlutfall kvenna sem meðhöndlaðar voru með íhaldssömum hætti vegna meðgöngunnar. Gallblöðrutökur á meðgöngu fóru einungis fram á fyrsta og öðrum priðjungi og flestar á fyrsta priðjungi, sem er svipað og í erlendum samantektum pó að góðum árangri hafi einnig verið lýst við aðgerðir á priðja priðjungi meðgöngu. ${ }^{18,25}$ Hugsanlegt er að einhverjar af peim 9 aðgerðum sem gerðar voru á fyrsta priðjungi hafi verið framkvæmdar án vitneskju um pungun, sem kann að skýra fjöldann á pessu tímabili. Ein gallblöðrutaka fór fram í opinni aðgerð í kjölfar keisaraskurðar á priðja priðjungi meðgöngu og pótti við hæfi að telja pað tilfelli með peim sem fóru í aðgerð að lokinni meðgöngu.

Framkvæmd gallblöðrutöku hjá punguðum konum krefst pess að ákveðin tæknileg atriði aðgerðarinnar séu aðlöguð að stækkuðu legi og áhrifum pess á konuna. Mælt er með að skápúði sé 
settur undir hrygg konunnar hægra megin til að forða pví að legið prýsti á neðri holæð (vena cava inferior) og skerði pannig blóðflæði til hjartans..$^{15}$ Pegar kemur að vali á staðsetningu fyrsta stingjar (trocar) er mælt með аð tekið sé tillit til legbolshæðar konunnar og íhugað hvort nota eigi opna aðferð (Hassan) í stað blindrar ísetningar stingjar í kviðarhol. ${ }^{15}$ Legslakandi lyf (tocolytics) í fyrirbyggjandi tilgangi meðan á aðgerð stendur hefur ekki sýnt sig að fækka fyrirburafæðingum en mælt er með að pau séu gefin ef vísbendingar vakna um yfirvofandi fyrirburafæðingu. ${ }^{15,26}$ Pá er mælt með notkun fósturrita bæði fyrir og eftir bráðar skurðaðgerðir hjá punguðum konum en ekki á meðan á aðgerð stendur. ${ }^{15}$

Lítið bar á fylgikvillum aðgerða en hvorki fósturlát né fyrirburafæðingar var hægt að rekja beint til gallblöðrutöku. Niðurstöður erlendis skýra frá svipuðum niðurstöðum hvað fósturlát varðar en fyrirburafæðingar virðast litlu tíðari, eða allt að 6,7\%. ${ }^{11}$ Í tveimur tilfellum (6\%) greindust steinar í gallgangi eftir gallblöðrutöku. Í grein Ólafar Viktorsdóttur og félaga frá 2004, um fylgikvilla gallblöðrutöku, kom fram að steinar í gallgangi eftir aðgerð hafi verið priðji algengasti fylgikvilli pessara aðgerða á eftir gallleka og blæðingu í kviðarhol með um 1,5\% tíðni. ${ }^{27}$
Meðalaðgerðartími var 63 mínútur og blæðing í aðgerðum óveruleg en pað er svipað og aðrir rannsakendur segja frá. ${ }^{11}$ Pyngdarstuðull sjúklinga í aðgerð var að meðaltali 31,1 sem er yfir offitumörkum og ASA-skor í flestum tilfellum 1 (bil:1-3). Svo hár meðalpyngdarstuðull er ekki óeðlilegur pegar tekið er tillit til pess að offita er stór áhættupáttur fyrir myndun gallsteina sem og að offita er tiltölulega algeng á Íslandi en 21\% kvenna hér var yfir offitumörkum á rannsóknartímabilinu. ${ }^{28}$

\section{Ályktanir}

Gallsteinasjúkdómar eru sjaldgæfir meðal pungaðra kvenna á Íslandi, með nýgengi svipað og á Vesturlöndum. Meðferð er örugg bæði með og án skurðaðgerðar og meðgöngutengdir fylgikvillar eru sjaldgæfir. Aðgerð með kviðsjá, framkvæmd á fyrsta og öðrum priðjungi meðgöngu, er örugg fyrir móður og barn. Niðurstöðurnar eru í samræmi við niðurstöður erlendra rannsókna.

Pakkir fyrir veitta aðstoð fá Sigríður Pála Konráðsdóttir, fyrrverandi ritari á deild 13A, Anna Haarde, skrifstofustjóri kvennadeildar og Guðrún Garðarsdóttir, ritari Fæðingarskrár.

\section{Heimildir}

1. de Bari O, Wang TY, Liu M, Paik CN, Portincasa P, Wang $\mathrm{DQH}$. Cholesterol cholelithiasis in pregnant women pathogenesis, prevention and treatment. Ann Hepato 2014; 13:. 728-45.

2. Ko CW. Risk factors for gallstone-related hospitalization during pregnancy and the postpartum. Am J Gastroenterol 2006; 101: 2263-8.

3. Ko CW, Beresford SAA, Schulte SJ, Matsumoto AM, Lee SP. Incidence, natural history, and risk factors for biliary sludge and stones during pregnancy. Hepatology 2005; 41: 359-65

4. Date RS, Kaushal M, Ramesh A. A review of the management of gallstone disease and its complications in pregnancy. Am J Surg 2008; 196: 599-608.

5. Bouyou J, Gaujoux S, Marcellin L, Leconte M, Goffinet F, Chapron $\mathrm{C}$, et al. Abdominal emergencies during pregnancy. J Visc Surg 2015; 152: S105-115.

6. Cox TC, Huntington CR, Blair LJ, Prasad T, Lincourt AE Augenstein VA, et al. Laparoscopic appendectomy and cholecystectomy versus open: a study in 1999 pregnant patients. Surg Endosc 2015; 30: 593-602.

7. Ghumman E, Barry M, Grace PA. Management of gallstones in pregnancy. Br J Surg 1997; 84: 1646-50.

8. Jorge AM, Keswani RN, Veerappan A, Soper NJ, Gawron AJ. Non-operative management of symptomatic cholelithiasis in pregnancy is associated with frequen hospitalizations. J Gastrointest Surg 2015; 19: 598-603.

9. Othman MO, Stone E, Hashimi M, Parasher G. Conservative management of cholelithiasis and its complications in pregnancy is associated with recurrent symptoms and more emergency department visits. Gastrointest Endosc 2012; 76: 564-9.
10. Jelin EB, Smink DS, Vernon AH, Brooks DC. Management of biliary tract disease during pregnancy: a decision analysis. Surg Endosc 2008; 22: 54-60.

11. Juhasz-Boss I, Solomayer E, Strik M, Raspe C. Abdominal surgery in pregnancy--an interdisciplinary challenge. Dtsch Arzteblatt Int 2014; 111: 27-8.

12. Dhupar R, Smaldone GM, Hamad GG. Is there a benefit to delaying cholecystectomy for symptomatic gallbladder disease during pregnancy? Surg Endosc 2010; 24: 108-12.

13. Muench J, Albrink M, Serafini F, Rosemurgy A, Carey L, Murr MM. Delay in treatment of biliary disease during pregnancy increases morbidity and can be avoided with safe laparoscopic cholecystectomy. Am Surg 2001; 67: 53942; discussion 542-3.

14. Lee S, Bradley JP, Mele MM, Sehdev HM, Ludmir J. Cholelithiasis in pregnancy: surgical versus medical management. Obstet Gynecol 2000; 95: S70-S71.

15. Pearl J, Price R, Richardson W, Fanelli R. Guidelines for diagnosis, treatment, and use of laparoscopy for surgical problems during pregnancy. Surg Endosc 2011; 25: 347992.

16. Hagstofa Íslands. „Fæðingartíðni 1990-2010.” http://px. hagstofa.is - nóvember 2015

17. Basso L, McCollum PT, Darling MR, Tocchi A, Tanner WA. A study of cholelithiasis during pregnancy and its relationship with age, parity, menarche, breast-feeding, dysmenorrhea, oral contraception and a maternal history of cholelithiasis. Surg Gynecol Obstet 1992; 175: 41-6.

18. Paramanathan A, Walsh SZ, Zhou J, Chan S. Laparoscopic cholecystectomy in pregnancy: An Australian retrospective cohort study. Int J Surg 2015; 18: 220-3.

19. Portincasa P, Moschetta A, Petruzzelli M, Palasciano G Di Ciaula A, Pezzolla A. Gallstone disease: Symptoms and diagnosis of gallbladder stones. Best Pract Res Clin Gastroenterol 2006; 20: 1017-29.
20. Anciaux ML, Pelletier G, Attali P, Meduri B, Liguory C, Etienne JP. Prospective study of clinical and biochemical features of symptomatic choledocholithiasis. Dig Dis Sci 1986; 31: 449-53.

21. Glasgow RE, Visser BC, Harris HW, Patti MG, Kilpatrick SJ, Mulvihill SJ. Changing management of gallstone disease during pregnancy. Surg Endosc 1998; 12: 241-6.

22. Lu EJ, Curet MJ, El-Sayed YY, Kirkwood KS. Medical versus surgical management of biliary tract disease in pregnancy. Am J Surg 2004; 188: 755-9.

23. Oelsner G, Stockheim D, Soriano D, Goldenberg M, Seidman DS, Cohen SB, et al. Pregnancy outcome after laparoscopy or laparotomy in pregnancy. J Am Assoc Gynecol Laparosc 2003; 10: 200-4.

24. Chen MM, Coakley FV, Kaimal A, Laros RK Jr. Guidelines for computed tomography and magnetic resonance imaging use during pregnancy and lactation. Obstet Gynecol 2008; 112: 333-40.

25. Bani Hani MN. Laparoscopic surgery for symptomatic cholelithiasis during pregnancy. Surg Laparosc Endosc Percutan Tech 2007; 17: 482-6.

26. Tan TC, Devendra K, Tan LK, Tan HK. Tocolytic treatment for the management of preterm labour: a systematic review. Singapore Med J 2006; 47: 361-6.

27. Viktorsdóttir Ó, Blöndal S, Magnússon J. Tíðni alvarlegra fylgikvilla gallkögunar. Læknablaðið 2004; 90: 487-90.

28. Valdimarsdóttir $\mathrm{M}$, Jónsson $\mathrm{SH}$, porgeirsdóttir $\mathrm{H}$, Gísladóttir E, Guðlaugsson JO, Pórlindsson P. Líkamspyngd og holdafar fullorðinna Íslendinga frá 1990-2007. Lýðheilsustöð, Reykjavík 2009. 


\section{ENGLISH SUMMARY}

\section{Gallstone disease during pregnancy at Landspitali University Hospital 1990-2010}

Hörður Már Kolbeinsson¹, Hildur Harðardóttir ${ }^{1,2}$, Guðjón Birgissonn ${ }^{1,3}$, Páll Helgi Möller ${ }^{1,3}$

Introduction: Gallstone disease in pregnant patients and their management in Iceland has not been studied. Management of these patients changed after the introduction of laparoscopic cholecystectomy. The aim of this study was to investigate the incidence, symptoms, diagnostic methods and management of gallstone disease during pregnancy at the National University Hospital of Iceland during the years 1990-2010.

Material and methods: This was a retrospective study and included all pregnant women admitted with gallstone diseases to the National University Hospital of Iceland which is the only tertiary hospital in Iceland. Information regarding age, symptoms and diagnostic methods for all women with gallstone disease along with BMI, ASA scores, pathology results and pregnancy related outcomes for women who underwent cholecystectomy were gathered.

Results: During the twenty year time period 77 women were admitted with gallstone disease in 139 admissions which makes incidence $0,1 \%$ amongst pregnant women. Diagnoses incuded biliary colic $(n=59)$, common bile duct stones $(n=10)$, acute cholecystitis $(n=7)$ and gallstone pancreatitis $(n=1)$. The most common symptom was RUQ pain $(n=63)$. Two preterm births were a direct consequence of gallstone disease. Fifteen women underwent cholecystectomy during pregnancy and 17 during the six week period after birth. Mean BMI was 31,1 and median ASA score was 1. Pathology reports showed chronic inflammation $(n=24)$ and acute inflammation $(n=5)$, one case included gallstones without inflammation Adverse outcomes of surgeries were two cases of gallstones left in the common bile duct. No stillbirths or preterm births resulted from cholecystectomies during pregnancy.

Conclusion: Gallstone disease during pregnancy is rare and readmissions are frequent. Pregnancy related complications are rare. Laparoscopic cholecystectomy is safe during pregnancy.

${ }^{1}$ University of Iceland, Faculty of Medicine, ${ }^{2}$ University Hospital of Iceland, Depts of Obstetrics and gynaecology and ${ }^{3}$ General Surgery.

Key words: gallstones, pregnancy, laparoscopic cholecystectomy.

Correspondence: Páll Helgi Möller pallm@landspitali.is 